Jean-Robert PITTE (sous la direction de): Paris, histoire d'une ville. Les Atlas Hachette, Paris, 1993, 192p., FF 335.

アシェットのアトラスの一冊として刊行されたも のであるが, 地図, 写真, 絵画を豊富に用いたパリ の歴史の解説書であると考えることもできる.

地理学者のジャン・バスティエなど 13 人の地理 学者, 考古学者, 歴史学者, 書誌学者などが協力し, 執筆している. 広範な読者層を対象にしたもので, 見開き 2 ページごとに展開されるトピックスの記述 はわかりやすいし, 読者を退屈させないが, 先史時 代から現在にいたるまでのパリの歴史を視覚的な材 料をふんだんに用い, 最新の研究成果を取り入れて 記述してあるので, パリの歴史の専門家によっても いくつかの新しい知見, 新しい史料の発見があるに ちがいない. 巻末に掲げられている資料の出典をみ ても本書が貴重な業績であることがわかるし, さら に掲げられている図やダイヤグラムの非常に多くが 本書のために新たにつくられたものであって, 本書 の制作のために大変なエネルギーが費やされている ことをも知ることができる. パリの歴史については 既往の膨大な文献があるが, 監修者ピットが序文で 述べているように, 視覚的な材料を用いてパリの過 去を総合的に復元する試みは, 前世紀後半の建築家 J. ホッフバウエ以降なされることはなかった. ホ ッフバウエ以降の先史学, 歴史学の研究の進展は著 しいし, 工業化の進展はパリの姿を一変させた. 事 実, このアトラスの約 3 分の 1 はコミューン以降の パリにあてられている. 2 巻本の『フランスの風景 の歴史』1)の著書もあるピットは, さまざまな尺度 の地図はもちろんのこと, 古い絵はがきにいたるま で貴重な史料を提供するのに成功している．彼の言 うように本書によって, 読者はセーヌのほとりでの 狩猟, 漁撈にはじまってバスティーユ・オペラ座の 開場にいたるまでの時空間を通じての知的刺激に満 ちた旅を楽しむことになる.

「ある都市の歴史」と題されたサブタイトルでい う「ある都市パリ」とは, 原則として現在のパリ市 の行政範囲であり，それはそれなりの歴史的根拠を もっているのであるが, 17 世紀から 18 世紀にかけ
てのヴェルサイユ宮殿の建設, 18 世紀における農 産物供給圏, 19 世紀末以降の郊外化之 1960 年のパ リ大都市圏計画 (PADOG) に代表されるような パリ大都市圏の成立と発展のように, 各所で現在の パリ市の行政区画にとらわれない言及がなされてい る. しかし主題はあくまで狭いパリ市なのであるか ら，物流や通勤交通あるいは不動産市場のように， パリ大都市圈という範囲でないと考察することがで きないような問題は，本書では取り上げられていな い. 旧市街地においても問題になるのではないかと 思われる最近におけるインナーシティや, ジェント リフィケーション, 再開発の問題も本書ではほとん ご取り上げられていない.これらの問題も大都市圈 亡いう枠組みのなかで論じられるべきであるという 監修者の見識を示すものであろうか. レ・アールに ついては 18 世紀末から 19 世紀前半にかけてのイ ノサン墓地跡の市場と 19 世紀後半バルタールによ って建設された建物の銅板画, 1975 年の掘り返さ れた建設現場の写真, ランジの新市場の図面と写真 はあるが, 現在のフォーラムの写真や図面はない.

本書のはじめには 8 ページにわたって, 政治・社 会, 経済, 都市計画 - 建築, 知的 - 宗教生活, 芸 術・科学の 5 つに分けた年表がま之められていて, 座右の参考資料として用いるのにも便利である。そ のあと各トピックが 9 つの章（第 1 版の目次には誤 植がある）にまとめられている. 第 1 章は自然条件 および先史時代にあてられており, 以後第 8 章まで は年代順の配列である.「パリの顔つき」(L'air de Paris）と題された第 9 章には,「パリの気候」(大 気污染や水害についても言及されている), 「歴史の 中におけるセーヌ川」,「首都の胃袋」,「パリの緑 地」,「パリの墓地」,「夜のパリ」,「美食の都パリ」, 「文学の都パリ」,「文化財と博物館」,「変りゆくイ ル・ド・フランス」といういかにもこの監修者らし いトピックスが並べられていて，ハイブロウ向きの ガイドブックの役割をも果たしている.

専門書としても画期的なものであり，同時に質の 高い啓蒙書でもある本書が, なんらかの形で日本語 に移され，日本の文化界に裨益することを期待した W. 
1) Jean-Robert Pitte: Histoire du paysage français. Tome I Le Sacré: de la préhistoire au XVe siècle, Tome II Le Profane: du XVIe siècle à nos jours, Tallandier, Paris, 1983.

(竹内啓一)

日本第四紀学会編 : 第四紀試料分析法 東京大学 出版会, 1993 年 8 月, A5 判, 〈 1 . 試料調査法 88 ページ, 図 7, 表 1, 2. 研究対象別分析法 574 ペ 一ジ, 図 202, 表 58>, 9, 500 円.

日本地理学会の隣接学会である日本第四紀学会が 企画して, 表記の 2 巻よりなる書を出版した. 本の 内容に入る前に出版の経緯を紹介しよう. 日本第四 紀学会は, 創立 30 周年記念刊行物として『日本第 四紀地図』を 1987 年に刊行したが（地図 4 葉と解 説, 東京大学出版会刊), つづいていくつかの特別 刊行物を企画した，その 1 つが『図解・日本の人類 遺跡』(東京大学出版会) で, 1992 年に出版され, 次いで本書の刊行となった. さらに $3 \sim 4$ 冊の出版 が予定されている.

本書は 9 人の編集委員（委員長は大場忠道）上 60 余人の執筆者によって作成された，第四紀にか かわる試料分析法を取りまとめた書物である. 評者 はこの出版はまことに時を得たものと思う. それと いうのは, 後記の多くの分析法の名称をみてもらえ ばわかるように, 近年の第四紀研究には, ここ 10 〜20 年に開発された多数の分析法がよく利用され ており，その成果は国内・国外の論文・報告書に広 くみられる. したがって，第四紀の研究を進めるに あたっては研究者個人が直接に，あるいは分析機関 を通じて間接に，各種の分析法を用いるようになっ たし，他方では論文・報告書の読者の側も分析法に ついての知識が必要になったのである.

第四紀の研究は，第四紀という，現代にいたる地 質時代の地球現象を対象亡するゆえに，時間的変遷 を扱うのは勿論であるが, 一方では地域に関する研 究でもあるという点で, 地理学に接している. とく に地理の諸分野のなかでは, 史的变遷の理解なしに は現在事象がわからない地形や，土壤・植生などを 含む自然環境ないし自然地理の研究と第四紀研究と は密接な関係にある．先史地理・歴史地理とも関係 が深い，本書が地理学界でおおいに利用されるとよ いと考えるゅえんである.
前置きが長くなったが, この本の内容に移ろう. 前記のように, 本書は薄くて軽い「1. 試料調查 法」と厚くて重い「2. 研究対象別分析法」に分け てある. それは, 1 巻は試料調查のあり方と分析の ための試料採取法を解説しており，野外携行を考え てのことという.この巻の内容はほぼ 2 巻の項目 （後記）に対応している，なお，巻末には「分析法 一覧」の表があって, 2 巻の分析法の要約になって いる.

2 巻の「研究対象別分析法」では, 下記の項目ご とに分析法の原理的なこと, 分析法の概略ないし詳 細, 分析の精度, 分析結果の表現法, 分析の事例や 問題点などが記されている. 分析法の中には 20 世 紀前半から始められたオーソドックスなものがある 一方, 先端技術利用の最新のものまであり, 日本で 始められたものも含まれている. 序文によれば, 本 書を読めば, 第四紀研究あるいは関連分野の初心者 でも，どのような目的のためには，どのような試料 採取法で, どんな分析法を用いれば, 何がじこまで わかるか，という見通しをもって研究計画をたてら れるように意図したという，つまり，研究する立場 の人を対象に作られた。しかし，はじめに記したよ うに, この本は研究成果の利用者にも役に立ち, と くに, 研究事例は具体的で理解を容易にする. それ に対して, 具体的な分析法の記述には, 方法や同定 に関する文献の紹介が十分でないと思われるものも ある. 実際のところ, 分析法に熟達するには, 弟子 入りが必要なものが少なくないであろう，以下には 内容を目次の項目で示そう.

\section{I. 土壤・堆積物編}

1. 土壤 : 炭素・室素分析法／腐植の形態分析法／ 鉄の形態分析法/マンガンの形態分析法 /リン分 析法

2. 堆積物 : 物理的性質の測定法/鉱物組成の同定 (粘土鉱物分析法 /一次鉱物同定法一実体 - 偏光 顕微鏡法/一次鉱物同定法-X線回析法) /堆積 物の組織（微細形態分析法/軟 $\mathrm{X}$ 線写真観察 法) /堆積環境の推定 (電気伝導度測定法/イオ ウ分析法/石英粒子表面分析法)

3. テフラ: 物理的性質の測定法 (温度変化型屈折 率測定法/キュリー温度法) /主成分・微量成分 (ICP 発光分析法/波長分散型 EPMA 法/エネ ルギー分散型 EPMA 法/機器中性子放射化分析 法／蛍光 X線分析法） 


\section{II. 化石編}

1. 微小植物: 花粉-胞子/植物珪酸体/珪藻/石 灰質ナンノプランクトン/瀜鞭毛藻

2. 大型植物 : 木材 $/$ 葉・果実・種子

3. 無脊椎動物: 有孔虫 /軟体動物 (貝類) (貝化 石／成長線解析法／酸素同位体法）／昆虫類

4. 脊椎動物 : 魚類 (耳石／鱗／咽頭歯)／両生類, 爬虫類, 鳥類, 哺乳類 (歯 - 骨の形態/微細構 造/タンパク質とアミノ酸分析法/脂肪酸分析 法/アイソトープ食性解析法)

5. 生痕 : 春椎動物の足跡/無脊椎動物一化石生管 を中心に

III. 遗物編

1. 石器

2. 土器: 形式-形態学的解析法/蛍光 $\mathrm{X}$ 線分析 法ノメスバウアー法

3. 木器

4. 骨器

5. 青銅器

6. 鉄器

IV． 年代測定法

年代測定法 : 種類, 原理, 特徴（カリウム・アルゴ ン法/フィッショントラック法/放射性炭素年代 測定法/ウラン系列法/熱ルミネッセンス法およ び電子スピン共鳴法/ラセミ化年代法／黑曜石水 和層法/古地磁気層序法)

このあとに, 参考書, 分析機関リスト, 索引など. まとめとして記すならば，このような本書は，第 四紀とその関連分野の分析法ハンドブックとしての 利用価值が非常に大きいといえよう.

（貝塚爽平）

菊地俊夫 : 日本の酪農地域 大明堂, 1993 年 2 月, A5 判, 258 ページ, 図 85, 写真 40 , 表 18 , 3, 450 円.

本書は関東地方における自立酪農経営の成立基盤 とその地域的差異を，主として事例地域における克 明な調查に基づいて, 解明することを課題としてい る.

周知のとおり日本農業は第二次世界大戦後急速に 変化したが, なかでも 1960 年代は歴史に残る大き な転機であった，さまざまな变化の側面のなかで, 米や麦, 雑穀, 豆類, いも類などの主穀作物の生産
の後退と, 野菜や果樹, 畜産といった商品作物生産 の伸びが，上くに目だった．本書で取り上げられた 酪農は, 第二次世界大戦後大きく発展をとげた商品 生産部門の 1 つであり, 酪農の推移を検討すること によって, 戦後の日本農業の動向をかなりの程度理 解することができる.

また, 当然のことながら酪農経営は, それぞれの 場所の自然条件や社会・経済的条件を反映して，さ まざまなかたちで展開してきた．本書は酪農経営を 類型化し，それぞれの類型を支えている地域の条件 を分析することによって, 農業の地域構造を明らか にしようという, 地理学にとって本質的で, 重要な 課題を追究している.

本書は 7 章から成り立っているが，それぞれの内 容を，かいつまんで紹介することにしよう．第1章 の序論では,これまで行なわれてきた酪農地域研究 の成果を検討し, 本書の課題上分析方法が説明され ている，まず；酪農を主体とする自立経営を「自立 酪農経営」と定義している，さらに，この自立酪農 経営を構成する農家と乳牛, 耕地, 施設・装備とい った要素に着目し、これらが地域の自然条件や社 会・経済的条件のもとで，どのように組織されてき たかを時間的・空間的に分析するという方法によっ て分析を進めることにした，それによって，自立酪 農経営の地域的性格と成立基盤を解明することを課 題としてあげている.

第 2 章では関東地方における酪農経営の発展を, 酪農家数之搾乳頭数之酪農家 1 戸当たり搾乳頭数な どの指標の推移と分布から，(1) 搾乳業者や搾乳牛 が現在の東京都内の範囲に集中していた 1921 年以 前の都市搾乳業期と，(2) 千葉県や神奈川県におけ る農民的酪農が台頭し始める 1922 年から 1940 年 までの農民的酪農萌芽期，（3）第二次世界大戦から 各都県の酪農家がピークに達する 1961 年までの酪 農普及期, (4) 酪農家が減少傾向になるが, 存続す るものは規模が拡大する 1962 年から 1977 年までの 酪農発展期，そして（5）酪農家 1 戸当たりの搾乳 頭数が 10 頭以上になりはじめた 1978 年以降を多頭 育酪農期に分けて整理した。 さらに, これらの時期 を通じて酪農経営の分布は, 中心から外縁に拡大す るとともに, 洪積台地や火山山簏など特定地域に集 中するようになったことを明らかにした。

第 3 章では酪農経営のうち自立経営を行なうもの を取り上げ，その分布変化を検討した. 1960 年に 
は大都市と地方中心都市の近郊に多かった自立酪農 経営は, 1980 年になると大都市近郊（都心から半 径 $50 \mathrm{~km}$ 圈内) と大都市近郊外縁部（都心から半 径 $100 \mathrm{~km}$ 圈内), 大都市遠郊（都心から半径 100 $\mathrm{km}$ 以上の圈域) に成立し, 外延的に拡大した. さ らに, 自立農業の集積地域を, 自然的条件と社会・ 経済的条件, および経営の諸条件から,「近郊酪 農」と「沖積低地中郊酪農」, 「洪積台地中郊酪農」, 「遠郊酪農」の 4 つに類型化し，とくに近郊酪農以 外は, 第二次世界大戦後の自立酪農経営の外方的な 立地移動に大きくかかわったので, それらの中から 事例を取り出し, 詳細に分析することにした.

第 4 章では「「沖積低地中郊酪農」の事例として利 根川下流地域の茨城県東村本新島開拓を, 「洪積台 地中郊酪農」の事例として茨城県出島村新生開拓之 群馬県藪塚本町桔梗ヶ原を取り上げた。これらの事 例研究ではまず, 酪農の発展と農業経営の变化を酪 農導入期之酪農発展期, 酪農多頭育期の 3 期に分け て検討し, さらに道路や集落, 耕地, 土地利用, 酪 農の施設や装備などの要素を含む景観の変化を明ら かにし, 最後に自立酪農経営の性格と存立条件につ いて考察している.

結果として,「沖積低地中郊酪農」は, 酪農の専 門化指向之家族農業労働力の強化, 調整牛之高経産 牛による乳牛飼養の多頭育化, 土地所有の集団化, 飼料作物による土地利用の集約化, 低廉な粕飼料の 多給, 酪農の施設装備の拡充によって発展した。な かでも, 飼養乳牛と飼料, 土地利用に特徵がみられ た. 他方, 「洪積台地中郊酪農」は酪農の専門化指 向と家族労働力の強化, 土地所有の集団化, 酪農の 施設装備の拡充によって発展したことについては, 沖積低地の場合と共通する. そして, 搾乳牛の自家 育成による乳牛飼養の多頭育化, 借地による経営規 模の拡大と飼料作物による土地利用の集約化という 条件に特徵がみら的た。

第 5 章では大都市遠郊の事例地域における自立酪 農経営を, 第 4 章と同様に, その成立過程と, それ に伴う景観変化, 自立酪農経営の性格亡存立条件に ついて検討した.この類型の自立酪農経営は, 酪農 の専門化指向と家族農業労働力の強化, 高等登録牛 による乳牛飼養の多頭育化, 乳牛の自家哺育之育成 の拡大, 土地所有の集団化, 経営規模の拡大, 飼料 作物による土地利用の単一化, サイレージ飼料の多 給, 酪農の施設装備の拡充によって発展した.
第 6 章は事例地域の分析によって得られたそれぞ れの類型の酪農の成立基盤の共通点と地域的差異を 検討している，共通する成立基盤としては，すでに 述べたように, 家族農業労働力之経営規模の拡大, 乳牛飼育規模の拡大, 飼料基盤の拡大, 土地所有の 集団化, 土地利用の集団化之単一化, 酪農の施設装 備の拡大と大型化などにより支えられ成立した．自 立酪農経営に地域的差異が生ずる重要な条件は飼料 基盤であり,「沖積低地中郊酪農」は耕地規模拡大 の可能性の低さを粕飼料への近接性と経営の集約化 で補い,「洪積台地中郊酪農」は借地により耕地規 模を拡大し,「遠郊酪農」は新たに耕地を開拓・拡 大することによって対応した。

また, 関東地方における自立酪農経営は主として 第二次世界大戦後の開拓地で発展したが,ここでは 水稲などの伝統的な農業生産基盤が脆弱であり, 耕 地規模拡大の可能性が大きかったため, 酪農などの ような有畜農業が導入されやすかった。開拓農家は 有畜農業の経験をもち, 団結力があり, 強いリーダ ーシップをもった指導者がいたことも，自立酪農経 営成立に大きくかかわっていた。

第 7 章ではこれまで述べた内容がまとめられてい る.

本書を通読してまず感じたのは，きわめて詳細で， 精力的な現地調查に基づいて収集された知見によっ て分析が進められていることである. しかも，取り 上げられた $6 つ の$ 事例のいずれについても, 密度の 濃い調查が行なわれている.これは著者の研究調査

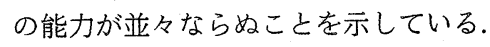

さらに, 現地調査への依存の程度が大きいとそれ ぞれの事例調查の間の整合性が薄れることが多いが, 本書では農家と乳牛, 耕地, 酪農の施設という 4 つ の要素から, 発展過程と景観, 酪農経営の地域的条 件を明らかにするという記述・分析スタイルをとり， 全体としてみごとに統一されている. しかも，それ らの事例が関東平野の自立酪農経営の主要類型とそ の分布パターンのなかに, 系統的に位置づけられて いる，また，観察や聞き取り，アンケート結果など を, 数值化したり, 地図化するとともに, 既存の統 計を効果的に使用して, 説得力を高めている.

ただ，あまりにもすべての事例が統一的・画一的 に記述・分析されているために，それぞれの地域の 個性が伝わりにくいようにも思える，事例によって 記述方法や分析の視点を少し変えてもよかったので 
はないかということを指摘するのは, ややぜいたく な注文であろうか.

この研究では景観観察から始まる精密な地域調査 を積み上げ, 系統的に整理し, 最後は酪農からみた 関東地方の地域構造を明らかにしている。 その構造 は大都市からの距離と自然条件, 開拓過程といった 歴史的・文化的条件によって規定されていることが 指摘されている。このような蟀納的な手法は, 最も 基本的で有効な地理学の研究姿勢の 1 つであり, 本 書は専門的な研究をめざす地理学者のための格好の テキストともいえよう.

また, 地理学の重要な使命の 1 つは現代の記述と いわれるが, 著者が直接観察や農家の人々からの聞 き取りによって得られた現在あるいは過去の地域の 状況の記録は，時代を経るにしたがって，ますます
価値を増すに違いない，さらに，どのように自立酪 農経営が形成され，そのためによ゙のような地域の条 件が重要であるかを明らかにしたことは，国際化に 伴う厳しい農業環境のもとで，これからの日本農業 の自立・発展を考えるよいヒントを与えてくれるに ちがいない，その意味では，地理学以外の分野の 人々にも薦めたい著作でもある。

著者は「あ亡がき」で，今後は，関東地方のみな らず日本全国の酪農地域についての分析と, 外国の 酪農地域との比較研究をめざし, すでに調査・研究 を始めていると述べているが, これらの成果が蓄積 され，ますます研究が深化していくことが楽しみで ある.

（田林 明）

\section{学 界消 息}

\section{本 学 会関 係}

第 21 回常任委員会 2月 19 日 (土) 10 時〜 13 時 30 分, 学会事務所にて開催. 出席者 : 中村常任 委員長, 青木, 大森, 小泉, 田林, 米倉の各常任委 員, 谷治涉外専門委員 (鈴木常任委員の代理), 奥 野次期常任委員長, 新井, 石井, 小疇, 高橋, 谷内, 野上の各次期常任委員, 小口庶務専門委員 (書記).

1. 入退会希望者について審議し, 入会正会員 8 名, 入会外国人正会員 1 名, 入会準会員 3 名, 退会 正会員 3 名 (小林一雄, 増澤譲太郎, 両角 節), 退会外国人正会員（フュックス・ローランド）を承 認した.

2. 研究奨励賞受賞候補者選考委員会の答申を承 認した。

3. 技術士試験への地理関係科目の導入に関する 要望書を科学技術庁長官に提出した.

4. 予稿集の定期購読制度が順調に機能している ことが報告された。

5. 春季学術大会の概要が説明された。 また 1995 年度春季学術大会は筑波大学で行なわれるこ とになった。

6. 各種委員会からの活動報告の内容を確認した.

7. 春季学術大会で永年会員候補者 191 名を表彰 することにした.

8. 国立の教員養成大学・学部の社会科系の修士
課程新設 ・大講座化に伴う地理学分野の非実験講座 化に関して，文部省に是正の要望書を提出すること にし，他学会にも同調を呼びかけることにした．

9. 次年度の研究作業グループの新設・継続・廃 止の希望について審議した。

10.「私たちの身のまわりの環境地図作品展」に 対する後援依頼を了承した.

11. 過去 5 年間に科学研究費の地理学分科で審查 し，採択された課題のリストを地理学評論に掲載す ることにした。

12. 次期の專門委員会・各種委員会の委員の候補 について検討した.

第 23 回編集専門委員会 2 月 12 日（土） 13 時 40 分〜16 時, 学会センタービル会議室にて開催. 出席者: 青木委員長, 大崎, 岡, 斉藤, 手塚, 徳永, 松村, 山下, 山村の各専門委員, 小疇次期編集委員 長.

1. 論説 4 編, 短報 2 編について閲読結果をもと に検討し, 論説 2 編 (中嶋, 高橋ほか) の受理を決 定した. 2. 新規投稿論文論説 5 編の担当委員, 閲 読者を決定した．3. 特集号の作業状況について報 告された.

第 1 回「都市気候特集号」編集委員会 2 月 19 日（土） 14 時〜 17 時, 学会センタービル会議室に おいて開催. 出席者 : 山下委員長, 岡, 菊地, 佐藤, 田宮の各委員. 


\section{会}

\section{第 7 回学協会共通問題に関する討論会についてのお知らせ}

1. 日 時 4 月 20 日（水） 13 時 16 時 20 分

2. 会

場 鹿島 KI ビル地下大会議室

電話 03-5561-2111

東京都港区赤坂 6-5-30 地下鉄千代田線赤坂駅下車徒歩 5 分

3. 協 賛 日本工学会加盟 88 学協会

4. 協 力 学術法人法制定運動賛同 180 学協会

5. 幹事学会、電気学会, 日本化学会, 日本機械学会, 日本鉄鋼協会, 日本物理学会

6. テーマ 学協会は今後いかにあるべきか一学術の国際化と教育・研究現場の変貌への対応—

7. プログラム

13:00 13:10 開会挨拶 石川六郎（日本工学会）

13:10 14:30 国際化に対する大学の教育・研究環境改革への諸問題.

司会 田中郁三（日本工学会）

13:10 13:30 市川惇信（日本学術会議第 4 常置委員会）：わが国における学術団体の現状

13:30 13:50 澤登俊雄 (日本学術会議第 3 常置委員会) : 大学教育・研究環境をめぐる諸問題

13:50 14:10 利谷信義（日本学術会議第 6 常置委員会）：国際学術交流と協力に関する諸問題および対策

14:10 14:30 長谷川裕恭（文部省学術国際局学術情報課）：学術法人への期待之行政施策の現状

$14: 30 \sim 14: 40$ 休稳

14:40 16:10 パネル討論会 “変革期に直面する学協会の行方”

司会 内田盛也 (日本工学会)

16:10 16:20 閉会挨拶 三井恒夫 (日本工学会)

7. 参加申し込みについて

参加費 1,000 円

参加申込 往復ハガキに氏名, 勤務先, 同住所, 同電話番号を明記したうえ, 返信八ガキ表に通信先住所・ 氏名を必ずご記入下さい.

申込期日 4 月 8 日（金）

申し込み先 $\overline{1} 107$ 東京都港区赤坂 9-6-41 社団法人日本工学会「学協会共通問題討論会」係あて 電話 03-3475-4621 FAX 03-3403-1738

平成 6 年度福武学術文化振興財団 学会・研究集会の開催に対する助成応募について

福武学術文化振興財団より標記助成の応募要項がとどきましたのでお知らせいたします。

1. 対 象 主として歴史学・地理学の自然科学的研究の分野に関係する学会・研究集会の開催に対して助成 する．歴史学・地理学とも国際性の高いもの，および未来志向的な内容のものを重視する.

2. 金 額 1 件につき 50 万円まで 総額 250 万円

3. 受 付 4 月 30 日(土)締切(平成 6 年 6 月 1 日 平成 7 年 5 月 31 日までに開催の学会・研究集会が対象)

4. 選 考 財団の規定による選考をもとに理事長が決定.

5. 決 定 申請受付後 1 カ月以内に決定し, 申請者（推薦者）に文書で通知する

申請手続きの詳細は下記へお問い合わせ下さい。

T206 東京都多摩市落合 1-34 財団法人福武学術文化振興財団 事務局

電話 0423-56-0810 担当 棚田 - 矢吹 


\section{他学会・研究会関係}

\section{4 年度地理科学学会春季学術大会の開催について}

1. 日時 5 月 15 日（日）

2. 場 所 広島大学西条キャンパス 東広島市鏡山 1-2-3

4. 内 容一般研究発表止よび総会, 懇親会

5 . 問い合わせ先，地理科学学会集会委員会

東広島市鏡山 1-2-3 広島大学文学部地理学教室内 電話 0824-22-7111 (代表)

\section{ASEAN Geographers Association (A. G. A.) Newsletter についてのお知らせ}

A. G. A. のニューズレター, No. 3 が発行されました. また第 3 回 ASEAN 地域地理学国際会議（1994 年 10 月 25 日〜29日) の申し込み用紙および東南アジア地形学会議仮登録用紙（1995 年 6 月 18 日〜23 日） も届いています，ご希望の方にお送りいたしますので下記にご連絡下さい．

連絡先 $\bar{T} 214$ 神奈川県川崎市多摩区营仙谷 2-33-8 平户幹夫

電話・FAX 044-944-0443

下記国際会議のお知らせもご参照下さい.

\section{国際会議のお知らせ}

会 議 名: International Association of Geomorphologists South East Asia Conference on Geomorphology

開 催 期 間: 1995 年 6 月 18 日 23日

開催地・会場 : Singapore

主催者・組織 : Nanyang Technological University and National University of Singapore

連 絡 先: Dr. GOH Kim Chuan, Division of Geography/NIE, Nanyang Technological University, 469 Bukitima Road, Singapore 1025. Tel: 4605181, Fax: 65-469-8433.

E-mail : Gohkc@nievax. nie. ac.sg

\section{各種学術賞・研究奖励金候補者の公募について}

\section{日本生命財団研究助成の公募について}

日本生命財団より 1994 年度の研究助成の公募がありましたので，お知らせいたします.

1. 研究助成対象「人間活動と環境保全との調和に関する研究」

2. 助成期間 1994 年 10 月 1 日から 1 年間

3 . 応募締切 5 月 20 日（金）(申請用紙申込締切は 5 月上旬まで)

上記の応募・お問い合せに関しては下記へご連絡下さい.

テ541 大阪市中央区今橋 3-1-7 日本生命今橋ビル $4 \mathrm{~F}$ 日本生命財団研究助成部 電話 06-204-4012 


\section{日本地理学会入会のご案内}

日本地理学会は, 1925 （大正 14）年に地理学の研究発展と普及に寄与することを目的に創立されました. 49 人の同人で始められた本会も, 現在約 3 千名の会員を擁し, 大学・小・中・高校の教員, 会社・官公庁の 研究者や実務担当者, 学生など広い層の会員から構成されています.

研究分野も地形・気候・水・環境などの自然地理, 農業・工業・人口・都市などの人文地理のほか, 国内国 外の各地域の自然・歴史・産業・文化などの総合的研究, 地図・リモートセンシング・地理情報システムなど, 広い分野にわたっています。

基礎研究のほか, 多くの会員が防災・地域振興・地理教育などの問題にも取り組んでいます.これらのテー マに関心をお持ちの方の入会をおすすめします.

\section{1. 事 業}

1) 地理学に関する研究・調查およびその奨励.

2) 機関誌「地理学評論 Ser. A」(月刊, 邦文), “Geographical Review of Japan, Ser. B” (年 2 回刊, 英文), その他図書の刊行.

3) 学術大会 (春・秋), 研究会, 講演会, 現地見学会などの開催.

4) 内外学術諸団体その他の機関との連絡.

5）その他本会の目的を達成するに必要な事業.

2. 会員の種別と資格

一般の会員には, 正会員と準会員があります.

- 正会員 本会の目的に賛同し年会費 (10,000 円) を納める個人.「地理学評論 Ser. A」定期購読, 研究発 表, 各種会合への参加, 各種役員の選挙権・被選挙権, 本会設備の利用等ができる.

・準会員 本会の目的に賛同する学部および大学院博士課程前期・修士課程またはこれに準ずる学校および課 程に在学している個人 (年会費 6,000 円).「地理学評論 Ser. A」の定期購読, 各種会合への参加 (発表はできない), 本会施設の利用ができる.

*既納の会費は原則として返却しません.

*なお, 欧文機関誌 “Geographical Review of Japan, Ser. B” の購読は, 別途 3,000 円が必要です.

3. 入会手続き

地理学に興味と関心をお持ちの方で, 本会の目的に賛同される方はごなたでも入会できます. 本号綴じ込み の日本地理学会入会申込書に必要事項をご記入のうえ, 日本地理学会までお送り下さい, 後日, 会費納入など についてご連絡いたします.

4. 会費の納入方法

1）郵便自動払込

2) 郵便振替（東京 4-12578 番）（会費納入のための振替用紙は4月上旬頃に各会員あて送付いたします）

3）このほかに，春・秋の学術大会の受付でも取り扱います.

準会員として入会をご希望の方はそのむね学会事務局へご連絡下さい. 入会申込書をお送りいたします. 


\section{4 年度秋季学術大会のお知らせ（第 1 報）}

1994 年度日本地理学会秋季学術大会は, 下記のとおり開催されることになりましたので, お知らせいたし ます.

1. 期 日 1994 年 10 月 15 日（土） 10月 16 日（日）（ただし評議員会は 10 月 14 日（金)）

2. 会 場 名古屋大学情報文化学部

3. 連絡先 干464-01 名古屋市千種区不老町

名古屋大学文学部 地理学教室 電話 052-789-2236 FAX 052-789-2272

4. 日 程 10 月 15 日（土） シンポジウム, 一般研究発表, ポスター・ビデオ・コンピュータセッシ ヨン, 懇親会

10 月 16 日（日） シンポジウム, 一般研究発表, ポスター・ビデオ・コンピュータセッシ ヨン, 研究作業グループ

\section{地理学関係博士・修士論文 (1993 年度) 題目等の報告についてのお願い}

日本地理学会では, 毎年, その年度に地理学関係で博士および修士の学位を授与された方の氏名と論文題目 を一括して地理学評論に揭載しております. 1993 年 4 月〜 1994 年 3 月の期間に学位を授与された博士論文・ 修士論文について，会員名簿に記載されている地理学関係の専攻課程の大学院をもつ大学にはすでに問い合わ せ済みですが，海外や，他専攻において学位を授与された博士論文・修士論文につきましては，下記の様式で 5 月 20 日までに学会事務所までお知らせ下さいますようお願いいたします.

○大学名, 〔博士論文・修士論文の別〕, 氏名 : 論文名

編集専門委員会 